Alexander G. Krivenko', Roman A. Manzhos ${ }^{1}$, Mitar Lutovac ${ }^{2}$, Sonja Ketin ${ }^{3 *}$

${ }^{1}$ Institute of Problems of Chemical Physics, Russian Academy of Sciences, Chernogolovka, Moscow Region, Russia,

${ }^{2}$ Union Nikola Tesla, Faculty of Management, Sremski Karlovci, Serbia, ${ }^{3}$ Faculty of Maritime Academic Studies, Belgrade, Serbia
Scientific paper

ISSN 0351-9465, E-ISSN 2466-2585

UDC:661.666.3/.4:093.3(n)

doi:10.5937/zasmat1804514K

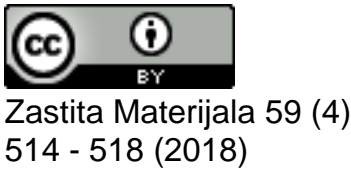

\title{
Oxygen reduction reaction on covalently and noncovalently modified carbon nanowalls
}

\begin{abstract}
An effect of highly oriented carbon nanowalls modification on oxygen reduction reaction was studied by means of a rotating disk electrode. Namely nanowalls were modified with oxygencontaining functional groups. Moreover, an adsorption of borneol (a surfactant with twodimensional structure) was considered. Two distinct waves are observed on voltammograms in aerated alkaline solutions that points out to the two-step process of oxygen reduction with the formation of $\mathrm{H}_{2} \mathrm{O}_{2}$ as intermediate. Both types of surface modification were found to affect substantially the absolute currents of the waves as well as their ratio. This effect was assumed to be caused by the topology peculiarities of carbon nanowalls that determine the electrochemical heterogeneity of the electrode surface. For initial nanowalls, the process of two-step reduction takes place on the edges of nanowalls. A parallel channel of oxygen reduction with the formation of water is assumed to be realized on the defects of basal planes at high overvoltage. In the case of noncovalent modification, borneol is adsorbed mainly on basal planes of nanowalls and blocks substantially parallel reduction channel. After covalent modification, oxygen reduction proceeds mainly through a two-step channel as a result of the increase in the number of oxygen-containing functional groups (the centers of two-step reduction) on the edges of nanowalls.
\end{abstract}

Keywords: carbon nanowalls, functionalization, adsorption, oxygen reduction reaction, rotating disk electrode.

\section{INTRODUCTION}

The number of publications on electrochemistry of carbon nanostructures greatly increased during last 10 years. However, the data presented in the literature are often controversial even on such fundamental electrochemical question as the dependence of reaction mechanism on the local topology of carbon surface (see, for example, Refs. $[1,2])$. The difficulty of objective comparison of the results for the electrodes based on various carbon nanoforms is caused by the uncertainty in the true surface available for the electrolyte. At the same time, a correct usage of the rotating disk electrode

\footnotetext{
${ }^{*}$ Corresponding author: Sonja Ketin

E-mail: sonja.ketin@vbs.edu.rs

Paper received: 25. 09. 2018.

Paper corrected: 24. 10. 2018.

Paper accepted: 30. 10. 2018.

Paper is available on the website: www.idk.org.rs/journal
}

(RDE) method results in the current values proportional to the geometrical surface of the electrode that would eliminate the problem of data comparability [3]. A special interest in materials based on carbon nanoforms is connected with the development of platinum free catalysts for oxygen reduction reaction (ORR). In particular, oxygen reduction proceeds via four-electron pathway on nitrogen doped carbon nanomaterials (nanotubes, graphene structures, highly oriented carbon nanowalls etc) [4-6] and the catalysts demonstrate overvoltages compared to Pt. However, in [7] edge sites of dopant free carbon nanowalls chemically evaporated on alumina nanofibers were assumed to be the centers of a four-electron pathway in ORR.

In the present study, the modification of CNWs was considered to elucidate the role of edges and defects of carbon nanowalls in ORR. Therefore, a RDE technique was used for the investigation of 
irreversible oxygen reduction reaction on initial and covalently/noncovalently modified electrodes based on highly oriented carbon nanowalls. A covalent modification with oxygen-containing functional groups was carried out by an electrolysis in water solution at high anodic potential. A noncovalent modification was an adsorption of borneol (an organic surfactant with two-dimensional structure). Both types of modification are described in detail in $[8,9]$ where a study of reversible redox-systems on initial and modified CNWs was perfomed by means of cyclic voltammetry.

\section{EXPERIMENTAL}

The measurements were carried out using a VED-06 rotating disk electrode set-up (Volta, Russia) and a IPC PRO-L potentiostat (A.N. Frumkin Institute of physical chemistry and electrochemistry of RAS, Russia) in a three electrode cell with common anodic and cathodic compartments filled with aerated solution of $0.1 \mathrm{M}$ $\mathrm{KOH}$. Platinum foil served as a counter electrode. $\mathrm{An} \mathrm{Ag} / \mathrm{AgCl}$ (sat. $\mathrm{KCl}$ ) electrode was used as a reference electrode. All potentials are referred to the reversible hydrogen electrode. The working electrode was assembled in the following way. The tablet of neodymium magnet was pressed into the end of hollow cylinder made of copper or aluminium. A nickel support with a CNW film obtained by the plasma enhanced chemical vapor deposition method [10] was attached to the magnet. A side surface of the assembling and a part of CNW layer on the support was isolated with chemically inert sealant forming a round working area $3 \mathrm{~mm}$ in diameter on the top of the electrode. Covalent modification of CNWs was realized by electrode polarization at $2.27 \mathrm{~V}$ during $2-3$ hours in deaerated $0.1 \mathrm{M} \mathrm{KOH}$ solution.

\section{RESULTS AND DISCUSSION}

Linear sweep voltammetry on initial and covalently modified CNWs is presented in the Fig. 1. These data were obtained in the $0.1 \mathrm{M} \mathrm{KOH}$ solution without and with addition of borneol at RDE rotation rate of $2000 \mathrm{rpm}$ and potential scan rate of $10 \mathrm{mV} / \mathrm{s}$. As can be seen from the figure, a wave of oxygen reduction is observed on CNWs in aerated solutions at $E \approx 0.45 \mathrm{~V}$. In accordance with the generally accepted conception (see, for example, Ref. [11]), the limiting current of the wave corresponds to the two-electron oxygen reduction to $\mathrm{H}_{2} \mathrm{O}_{2}$.

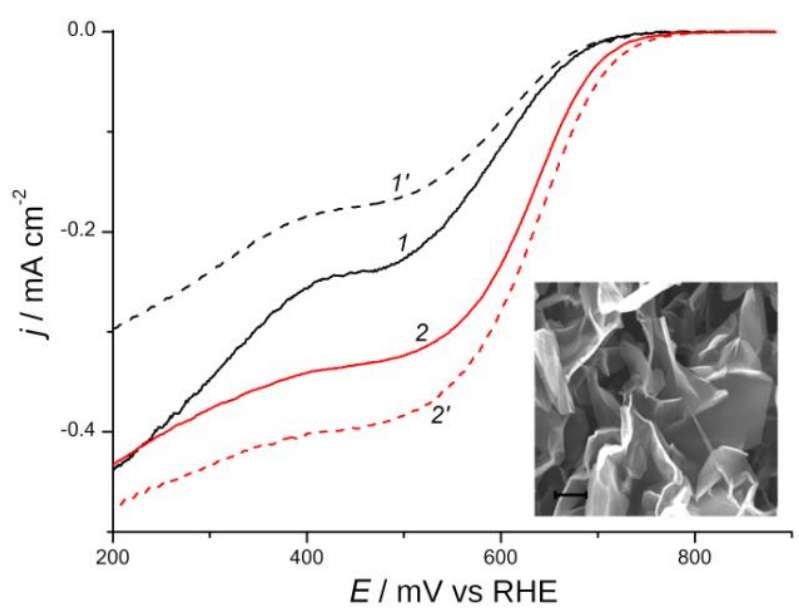

Figure 1. Linear sweep voltammetry on initial (1, 1') and covalently modified (2, 2') CNWs in aerated 0.1 $M \mathrm{KOH}(1,2)$ and $0.1 \mathrm{MKOH}+10^{-3} \mathrm{M}$ borneol (1', $\left.2^{\prime}\right)$ solutions at $R D E$ rotation rate of $2000 \mathrm{rpm}$ and potential scan rate of $10 \mathrm{mV} / \mathrm{s}$. The inset shows a scanning electron microscopy image of the CNW film (reproduced with permission from Ref. [8]). Scale is $500 \mathrm{~nm}$.

Slika 1. Linearna voltametrija pranja na inicijalnom $\left(1,1^{\prime}\right)$ i kovalentno modifikovanom (2, 2') CNV u aerodiranom $0.1 \mathrm{M} \mathrm{KOH}(1,2)$ i $0.1 \mathrm{M} \mathrm{KOH}+10-3$ $M$ borneola (1', 2 ') rastvorima sa brzinom rotacije RDE od 2000 obr / min i potencijalnim skeniranjem od $10 \mathrm{mV} / \mathrm{s}$. Uložak prikazuje skeniranje elektronske mikroskopske slike CNV filma (reprodukovano dozvolom iz Ref. [8]). Skala je $500 \mathrm{~nm}$.

To determine the number of electrons $n$ involved in the ORR on initial CNWs, a linear sweep voltammetry was carried out at different electrode rotation rates $\omega$. The Koutecky-Levich equation [12] was used to analyze the obtained data:

$$
\begin{aligned}
& \frac{1}{j}=\frac{1}{j_{\mathrm{k}}}+\frac{1}{j_{\mathrm{d}}}, \\
& j_{k}=n F k c^{0}, j_{d}=0.62 n F D^{2 / 3} \omega^{1 / 2} u^{-1 / 6} c^{0}
\end{aligned}
$$

where $j_{k}$ is the density of kinetic current, $j_{d}$ is the density of the limiting diffusion current, $F$ is the Faraday constant $\left(\mathrm{F}=96485 \mathrm{C} \mathrm{mol}^{-1}\right), \mathrm{D}$ is the diffusion coefficient of oxygen in $0.1 \mathrm{M} \mathrm{KOH}$ solution $\left(D=1.9 \cdot 10^{-5} \mathrm{sm}^{2} \mathrm{~s}^{-1}\right), u$ is the kinematic viscosity of $0.1 \mathrm{M} \mathrm{KOH}$ solution $\left(u=0.01 \mathrm{sm}^{2} \mathrm{~s}^{-1}\right)$, $c^{0}$ is the bulk concentration of dissolved oxygen $\left(c^{0}\right.$ $=0.24 \mathrm{mM}$ in $0.1 \mathrm{M} \mathrm{KOH}$ solution) $[5,13]$. The dependence of the electron number involved in the oxygen reduction on initial CNWs on the electrode potential is demonstrated in the Fig. 2. As seen 
from the figure, the $n$ value increases from ca 1.7 to ca 2.1.

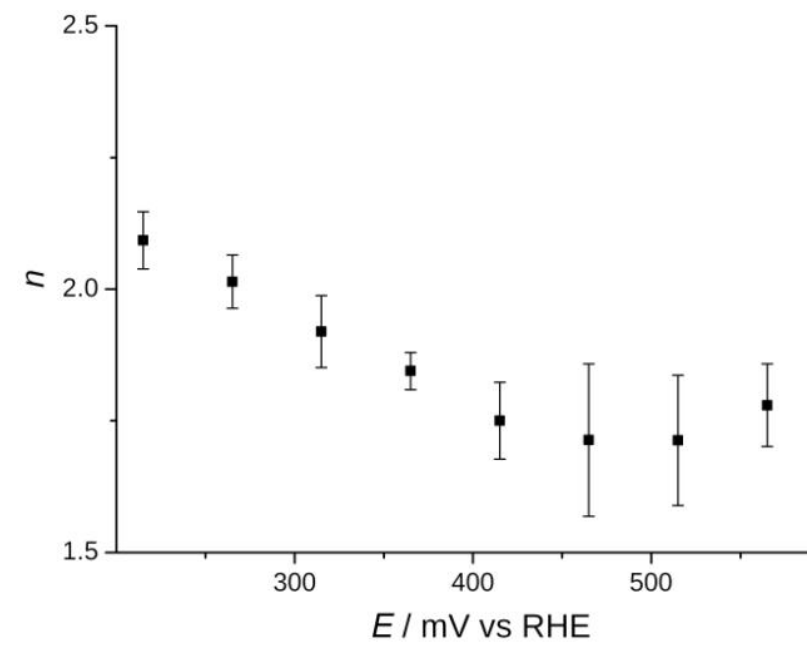

Figure 2. The dependence of the electron number involved in the oxygen reduction on initial CNWs on the electrode potential.

Slika 2. Zavisnost broja elektrona uključenih u redukciju kiseonika na početne CNV-ove na potencijal elektrode.

At lower overvoltage, a reduction of $\mathrm{O}_{2}$ to $\mathrm{H}_{2} \mathrm{O}_{2}$ takes place on the most «active» centers. At transition to more negative potentials, a parallel channel of oxygen reduction to hydrogen peroxide at «less active» centers engages in the overall oxygen reduction process. The evidence in favor of this hypothesis is the fact that a typical diffusion length of $0.7-1.2 \mu \mathrm{m}$ for used rotation rates of the electrode [12] is comparable with the size of the structure element of nanowalls (the inset of Fig. 1). It follows from the above that diffusion layers of individual "active" and "less active» centers do not overlap and the registered current is a sum of the currents on these centers [14]. According to the generally accepted conception (see, for example, Ref. [15]), edges of nanowalls are assumed to be the most active centers and the structural defects of basal planes correspond to less active centers. It is worth mentioning that similar effect is observed for different silver nanocrystals.

A two-step process is a typical one for cubic particles, and a one-step process involving a transfer of four electrons occurs on nanocrystals of more complex shape with large angles between the facets [16]. As for carbon nanoforms, a fourelectron oxygen reduction is described in numerous publications on doping of graphene and carbon nanotubes by non-metal atoms $(\mathrm{N}, \mathrm{S}, \mathrm{P}, \mathrm{I}$, F) $[4,17,18]$. However, in some works $[19,20]$, such a process is assumed to proceed also on the defects of basal planes decorated with oxygencontaining groups.

The addition of borneol (curve 1') results in the decrease in the current. This effect can be explained by the preferential adsorption of borneol on the basal planes which blocks the centers (surface defects) of molecular oxygen adsorption and reduction via parallel pathway. At the same time, borneol adsorption on the edge regions seemed to be more hampered. This assumption is in a good agreement with the conclusions [8, 9] about the mechanism of surfactant influence on the kinetics of redox processes on CNW electrodes.

After covalent modification of CNWs, the limiting current increases (curve 2) ca 1.4 times. Electrochemical functionalization of CNWs used in the current study was shown $[8,9]$ to result in increase in the number of oxygen-containing functional groups preferentially located on the edges of nanowalls $\left([\mathrm{O} / \mathrm{C}]_{\text {at }}\right.$ atomic ratio is 0.02 0.03 and 0.14 for the initial and modified CNWs respectively). Moreover, there was a partial splitting of nanowalls $[8,9]$. It is important to note that the data of Raman spectroscopy did not reveal an increase in the defectiveness of the CNW basal planes after functionalization. In [21] a catalytic activity of the edges of graphene basal planes toward ORR was found to increase after decoration with oxygen-containing groups. In our case, an increase in the number of «active» centers (in the first approximation, functional groups on the edges of splitted nanowalls) obviously results in the decrease in a typical distance between these centers and overlap of their diffusion layers. The latter will cause a virtually full "turn-off» of the parallel pathway reduction centers on basal planes. The addition of borneol (curve 2') does not lead to the substantial change of voltammogram. A negligible increase in the current is only observed. This observed weak effect on the ORR kinetics for functionalized CNWs is in agreement with the assumption about preferential adsorption of borneol on basal planes resulting in the blockage of oxygen adsorption on «less active» centers.

\section{CONCLUSIONS}

Despite any model approximation, the kinetics of oxygen reduction on CNW electrode was shown to be changed substantially as a result of covalent or noncovalent modification. This effect on ORR was assumed to be caused by the topology peculiarities of highly oriented carbon nanowalls. 
The process of oxygen reduction with the formation of $\mathrm{H}_{2} \mathrm{O}_{2}$ takes place on the edge regions of graphene planes. At high overvoltage a reduction of $\mathrm{O}_{2}$ to $\mathrm{H}_{2} \mathrm{O}_{2}$ takes place on the defects of basal planes of initial CNWs. At noncovalent modification, borneol is preferentially adsorbed on the basal planes and it blocks parallel reduction channel. Covalent modification increases the number of oxygen-containing functional groups («active» centers) on the edge regions of nanowalls.

\section{Acknowledgements}

This study was supported by the Russian Science Foundation (project no. 17-73-20236).

\section{REFERENCES}

[1] W.Yuan, Y.Zhou, Y.Li, C.Li, H.Peng, J.Zhang, Z.Liu, L.Dai, G.Shi (2013) The edge- and basalplane-specific electrochemistry of a single-layer graphene sheet, Sci. Rep., 3, 2248-2255.

[2] L.Wang, A.Ambrosi, M.Pumera (2013) Could carbonaceous impurities in reduced graphenes be responsible for some of their extraordinary electrocatalytic activities?, Chem.Asian J., 8, 12001204.

[3] Yu.V.Pleskov, V.Yu.Filinovskii (1972) Rotating disk electrode (In Russian) Nauka, Moskva, p.344.

[4] J.Liu, P.Song, Z.G.Ning, W.L.Xu (2015) Recent advances in heteroatom-doped metal-free electrocatalysts for highly efficient oxygen reduction reaction, Electrocatalysis, 6, 132 -147.

[5] L.T.Qu, Y.Liu, J.B.Baek, L.M.Dai (2010) Nitrogendoped graphene as efficient metal-free electrocatalyst for oxygen reduction in fuel cells, ACS Nano, 4, 1321-1326.

[6] J.P.McClure, J.D.Thornton, R.Z.Jiang, D.Chu, J.J.Cuomo, P.S.Fedkiw (2012) Oxygen reduction on metal-free nitrogen-doped carbon nanowall electrodes, J. Electrochem. Soc., 159, 733 - 742.

[7] S.N.Stamatin, I.Hussainova, R.Ivanov, P.E.Colavita (2016) Quantifying graphitic edge exposure in graphene-based materials and its role in oxygen reduction reactions, ACS Catalysis, 6, 5215-5221.

[8] A.G.Krivenko, N.S.Komarova, E.V.Stenina, L.N.Sviridova, K.V.Mironovich, Y.M. Shul'ga, R.A.Manzhos, S.V.Doronin, V.A.Krivchenko (2015) Electrochemical modification of electrodes based on highly oriented carbon nanowalls, Russ. J. Electrochem., 51, 963-975.

[9] N.S.Komarova, A.G.Krivenko, E.V.Stenina, L.N.Sviridova, K.V.Mironovich, Y.M. Shulga, V.A. Krivchenko (2015) Enhancement of the carbon nanowall film capacitance. Electron transfer kinetics on functionalized surfaces, Langmuir, 31, 7129-7137.

[10] K.V.Mironovich, D.M.Itkis, D.A.Semenenko, S.A. Dagesian, L.V.Yashina, E.Y.Kataev, Y.A.Mankelevich, N.V.Suetin, V.A.Krivchenko (2014) Tailoring of the carbon nanowall microstructure by sharp variation of plasma radical composition, Phys.Chem.Chem.Phys., 16, 25621 25627.

[11] R.J.Taylor, A.A.Humffray (1975) Electrochemical studies on glassy carbon electrodes: II. Oxygen reduction in solutions of high $\mathrm{pH}(\mathrm{pH}>10), J$. Electroanal. Chem., 64, 63-84.

[12] A.J.Bard, L.R.Faulkner (2001) Electrochemical methods: Fundamentals and applications, 2nd edn., John Wiley \& Sons, Inc., p.864.

[13] G.Jurmann, K.Tammeveski (2006) Electroreduction of oxygen on multi-walled carbon nanotubes modified highly oriented pyrolytic graphite electrodes in alkaline solution, J. Electroanal. Chem., 597, 119-126.

[14] K.Ngamchuea, S.Eloul, K.Tschulik, R.G.Compton (2014) Planar diffusion to macro disc electrodeswhat electrode size is required for the Cottrell and Randles-Sevcik equations to apply quantitatively? J. Solid State Electrochem., 18, 3251-3257.

[15] A.Shen, Y.Zou, Q.Wang, R.A.W. Dryfe, X. Huang, S.Dou, L.Dai, S.Wang (2014) Oxygen reduction reaction in a droplet on graphite: direct evidence that the edge is more active than the basal plane, Angew. Chem., Int. Ed., 53, 10804-10808.

[16] Q.Wang, X.Cui, W.Guan, L.Zhang, X.Fan, Z.Shi, W.Zheng (2014) Shape-dependent catalytic activity of oxygen reduction reaction (ORR) on silver nanodecahedra and nanocubes, J. Power Sources, 269, 152-157.

[17] H.L.Poh, M.Pumera (2015) p-Element-doped graphene: Heteroatoms for electrochemical enhancement, Chem Electro Chem, 2, 190-199.

[18] Q.G.He, E.J.Cairns (2015) Review-Recent progress in electrocatalysts for oxygen reduction suitable for alkaline anion exchange membrane fuel cells, J. Electrochem. Soc., 162, 1504-1539.

[19] W.I.Hayes, P.Joseph, M.Z.Mughal, P.Papakonstantinou (2015) Production of reduced graphene oxide via hydrothermal reduction in an aqueous sulphuric acid suspension and its electrochemical behaviour, J. Solid State Electrochem., 19, 361-380.

[20] E.P.Randviir, C.E.Banks (2014) The oxygen reduction reaction at graphene modified electrodes, Electroanalysis, 26, 76-83.

[21] Y.Zhou, S.L.Chen, S.W.Liu, Q.Liu, H.Q.Hou, F.Zhao (2014) Electrocatalytic activity of carbon nanoparticles from diffusion flame towards oxygen reduction, Electrochim. Acta, 136, 176-181. 


\title{
IZVOD
}

\section{REAKCIJA REDUKCIJE KISEONIKA NA KOVALENTNO I NE-KOVALENTNO MODIFIKOVANE NANOCEVI UGLJENIKA}

Proučavan je efekat visoko-orijentisane modifikacije ugljeničnih nanovalls na reakciju redukcije kiseonika pomoću rotirajuće diskove elektrode. Naime, nanovalls su modifikovani sa funkcionalnim grupama koje sadrže kiseonik. Štaviše, razmotrena je adsorpcija borneola (surfaktant sa dvodimenzionalnom strukturom). Dva različita talasa se posmatraju na voltamogramima u aeracionim alkalnim rastvorima koja ukazuju na dvostepeni proces redukcije kiseonika uz formiranje $\mathrm{H}_{2} \mathrm{O}_{2}$ kao intermedijera. Utvrđeno je da oba tipa površinske modifikacije značajno utiču na apsolutne struje talasa, kao i njihov odnos. Pretpostavlja se da je ovaj efekat prouzrokovan topološkim karakteristikama nanošenja ugljenika koji određuju elektrohemijsku heterogenost površine elektrode. Za početne nanovalls, proces redukcije u dva koraka se odvija na ivicama nanovalls-a. Pretpostavlja se da se paralelni kanal redukcije kiseonika sa formiranjem vode realizuje na defektima bazalnih ravnina pri visokom prenaponskom naponu. U slučaju nekovalentne modifikacije, borneol se adsorbuje uglavnom na bazalnim ravninama nanovalls-a $i$ blokira u suštini paralelni kanal redukcije. Nakon kovalentne modifikacije, smanjenje kiseonika ide uglavnom kroz dvostepeni kanal kao rezultat povećanja broja funkcionalnih grupa koje sadrže kiseonik (centri dvostepenog smanjenja) na ivicama nanovalls-a.

Ključne reči: ugljenične nanocevi, funkcionalizacija, adsorpcija, redukcija kiseonika, rotirajuća disk elektroda.

\author{
Naučni rad \\ Rad primljen: 25. 09. 2018. \\ Rad korigovan: 24. 10. 2018. \\ Rad prihvaćen: 30. 10. 2018. \\ Rad je dostupan na sajtu: www.idk.org.rs/casopis
}

(c) 2018 Authors. Published by Engineering Society for Corrosion. This article is an open access article distributed under the terms and conditions of the Creative Commons Attribution 4.0 International license (https://creativecommons.org/licenses/by/4.0/) 